\title{
10. New Zealand: electoral politics in times of crisis
}

\author{
Michael Jones
}

\section{From crisis to crisis to elections}

For the scholar of crisis leadership, the New Zealand Government's response to the 2008-09 global financial crisis represents a distinct and interesting case study. The combination of three characteristics in particular renders it unique. First, New Zealand's small, open economy is heavily dependent on trade, particularly in agricultural products; consequently, even in the best circumstances, it is hopelessly vulnerable to the vagaries of commodity prices in the international economy. Second, when the crisis hit New Zealand it was already in the grip of a home-grown economic downturn, attributable to a severe drought and a slowing of the housing market. Finally, the occurrence of the crisis immediately before a general election, on 8 November 2008, ensured that attempts by leaders to interpret economic events were intensely politicised and contested.

This chapter will analyse the leadership of key players in New Zealand's experience of the global financial crisis through an application of the theoretical framework advanced by Boin et al. (2009; see also Chapter 2, this volume). As a caveat to their theoretical model, Boin et al. (2009:95, 98-9) observe that situational and temporal factors can significantly influence the course and outcomes of a crisis. As suggested in the opening lines of this chapter, the course and outcomes of the global financial crisis in New Zealand are certainly no exception. Indeed, the three aforementioned characteristics, which render the case unique, have important implications for any attempted analysis.

The first situational factor-New Zealand's small, open economy-influenced crisis leadership in conflicting ways. In one sense, it allowed New Zealand's leaders to externalise blame for the crisis more easily, but at the same time, it gave them very limited ability to reduce its impact. Consequently, the master narrative of the crisis in New Zealand was not one of climactic, unforeseen events; indeed, domestic banking and financial institutions remained relatively strong (Bollard 2008c). Rather, it was a narrative of steady decline in growth and steady rises in oil and food prices-following developments in international markets - until a recession was declared on 5 August 2008. Tellingly, Morgan Research's (2008d) consumer confidence polling suggested that the New Zealand public, having felt the sting of an international downturn during the 1997-98 
East Asian financial crisis, were aware of their vulnerability to international developments, and their confidence fell away accordingly.

The second situational factor - the home-grown downturn — was also significant. This was because it was in the interest of all political actors, at various times, for the framing of the two crises to become linked. Early in the period, the Clark Government sought to link the developing international crisis to the domestic downturn in order to escape blame for the latter. Later on, the new Key Government sought to establish a similar link in order to blame the Clark Government for the effect of the former.

Finally, the significance of the November general election as a temporal factor cannot be overstated. In particular, this was because all early pre-election polls strongly suggested that the vote would produce a change of government (Morgan Research 2008a; One News-Colmar Brunton 2008a; TV3-TNS 2008). The coincidental occurrence of elections heavily skewed all media coverage and popular perception of the crisis towards its impact as an electoral battleground. This resulted in two very different narratives running through the leadership of the crisis: one of a long-standing government desperately struggling against its decline; the other of a long-standing opposition seizing its first opportunity to govern in more than a decade.

\section{Methodological considerations}

The advent of a change in government during the period under study prevented this chapter from focusing on three central leaders, as in most of the case studies within this volume. Instead, in this chapter, the focus of analysis is on two key economic leaders within each of the two governments in office during the period: the Prime Ministers Helen Clark and John Key, and the Ministers of Finance Michael Cullen and Bill English. The New Zealand electoral context also renders problematic the figure of Dr Alan Bollard, the Governor of the Reserve Bank of New Zealand (RBNZ), whose equivalent is considered in the other case studies. By convention in New Zealand, the RBNZ Governor attempts to keep a low profile during the lead-up to an election so as to keep the office de-politicised. Bollard upheld this convention, limiting himself largely to the legally required monthly 'monetary policy statements' and biannual 'financial stability statements' during a period that was unfortunately simultaneous with the emergence of the crisis (Bennet 2008).

Additionally in New Zealand, the Department of the Treasury (Kaitohutohu Kaupapa Rawa) is charged with a unique, bipartisan public information function under Section 26T of the Public Finance Act 1989. This became especially significant in an electoral context when it was required to publicly release a Pre-Election Economic and Fiscal Update (PREFU) and a Briefing to the incoming minister, as it did at the height of the crisis. To account for these characteristics 
of the case, this chapter includes the two Treasury releases during the period of the election, as well as two speeches made by Governor Bollard when he resumed his public framing role after the election.

The analysis of each speech act contains two components situating it in terms of the framing contests and rhetorical strategies described in Chapter 2, and then gauges the public reception of the speech, through analysis of three of New Zealand's newspapers: the Dominion Post, The Press and the New Zealand Herald. Quantitatively, the media response is represented in tabular form with each responding article coded as agreeing, remaining neutral or disagreeing with four aspects of the speech's framing: 1) its framing of crisis severity; 2) its framing of crisis causation; 3) its framing of the proposed policy response; and 4) support for the speech-maker (for the references supporting each table, see the online appendix at $<$ http://globalfinancialcrisis.wetpaint.com/ $>$ ). This quantitative analysis is followed by qualitative analysis examining the degree to which the media responses accept, adopt or reject the frame's narrative of the crisis. In the case of the frames put forward by the Treasury and the RBNZ, which are apolitical and not widely covered in the media, the chapter will proceed directly to qualitative analysis.

The three papers selected for analysis were chosen to provide a representative sample of New Zealand's print media. First, according to polling by Nielson Media Research New Zealand (2008), they were the three highest-circulating papers in New Zealand in 2008. Second, they are published in each of New Zealand's three largest regional centres: the Dominion Post is published in the capital, Wellington (southern North Island); The Press is published in Christchurch (South Island); and the New Zealand Herald is published in Auckland (northern North Island). Moreover, Nielson's polling also suggests they have the dominant readership within the region surrounding their centre of publication. This was considered important to account for any regionally specific perspectives on the crisis. Finally, the three papers - while all centrist and more provincially than ideologically defined-represent a fair ideological spectrum.

\section{Box 10.1 New Zealand's financial crisis trajectory, November 2007 - December 2008}

November 2007: Reserve Bank of New Zealand (RBNZ) Governor Dr Alan Bollard, releases the biannual 'Financial stability report' reassuring New Zealanders that New Zealand banks have virtually no direct exposure to the US sub-prime market and have engaged in very little securitisation. He warns, however, that as funding costs rise, credit conditions will tighten (Bollard 2007). 
6 March 2008: Bollard (2008a) warns that there is a risk that the slowdown in the US economy and international financial market turbulence could result in a sharper downturn in New Zealand.

7 May: Bollard (2008c) says New Zealand's financial system has so far withstood 'a severe test from global financial markets' and has 'very little exposure to offshore credit risk or structured debt products'.

22 May: The New Zealand Treasury (2008a) releases the Budget Economic and Fiscal Update (BEFU). Finance Minister, Michael Cullen, delivers the 2008 New Zealand budget.

5 June: Bollard releases his 'June monetary policy statement' in which he announces that the official cash rate (OCR) will remain unchanged and now projects little to no gross domestic product (GDP) growth in 2008 and only a modest recovery thereafter (Bollard 2008d).

27 June: Statistics New Zealand releases its quarterly GDP update, 'Gross domestic product: March 2008 quarter'; these are the first strong indicators that New Zealand is headed for recession (Statistics New Zealand 2008).

8 July: The New Zealand Institute of Economic Research's (NZIER 2008) Quarterly Survey suggests New Zealand is technically in recession.

5 August: The New Zealand Treasury's Overview of July Economic Indicators (2008b) predicts that the economy will slide into technical recession.

II September: Bollard releases his 'September monetary policy statement' (Bollard 2008e) in which he announces that the OCR will be reduced by 50 points to 7.5 per cent and projects continuing inflation and possibly further OCR reductions.

6 October: The New Zealand Treasury (2008c) delivers its Pre-Election Economic and Fiscal Update (PREFU).

8 November: New Zealand General Election.

12 November: Bollard releases his biannual 'Financial stability report' (Bollard 2008f). He states that New Zealand's banks are well positioned to withstand the economic downturn. Deputy Governor, Grant Spencer, assures New Zealanders that their deposits are safe.

I9 November: John Key's Government is sworn into office.

4 December: Bollard releases his 'December monetary policy statement' in which he announces reductions in the OCR to 5 per cent, bringing the cumulative reductions since July to 3.25 per cent (Bollard 2008g). 
4 December: The New Zealand Treasury releases Briefing to the incoming Minister of Finance 2008: medium-term economic challenges (Treasury 2008d).

I8 December: The New Zealand Treasury releases Economic and Fiscal Forecasts: December 2008 (Treasury 2008e).

\section{Crisis development and elite rhetoric in New Zealand}

\section{May 2008: Prime Minister Clark's budget speech}

On 22 May 2008, Michael Cullen unexpectedly seized on gloomy forecasts in the Treasury's Budget Economic and Fiscal Update (Treasury 2008a) to cast his budget as a response to uncertain times (Cullen 2008a). The next day, in her traditional, post-budget address to the Auckland Chamber of Commerce, Clark went further than any New Zealand economic leader had to date. The Prime Minister book-ended her explanation of the budget with cautionary rhetoric. She opened by stating that 'this year's budget has been written against the background of a slower global economy which has obvious ramifications for New Zealand' and concluded with a reminder that the budget had been 'written against external factors which are not what any of us would want but which we have to work around'. She was not specific about the severity of the global financial crisis, which she described as 'the fall out of the sub-prime crisis in the United States', which 'has been felt around the world'. She did, however, place it at the centre of a confluence of externally caused factors that had resulted in a sufficiently severe 'backdrop' to which the budget had been tailored to respond. She supported the budget's combination of stimulus investments in infrastructure and tax relief for struggling families as the best policy response to this crisis.

Within the analytical framework, Clark's speech suggests that her decision to begin framing came well before she could have made accurate sense of, or decided on any response to, the global crisis (at least based on Treasury's numbers). Her frame emphasised the severity of the crisis, justifying an about-turn on tax cuts in the budget. It stressed the threat the crisis posed to the prosperity that New Zealanders had enjoyed under her (status quo) government. Clark's intention seems to have been to link the frame of the home-grown downturn to that of the international crisis, and thus exogenise any blame attributable to her government for the former.

Clark's framing highlights the dangers of viewing crises as discreet political episodes, particularly when calculating the intent of actors. Boin et al. (2009:85) posit that a political risk of overemphasising the severity of a crisis is to be accused of being 'alarmist' or 'opportunist'. Clark clearly accepted this risk, but 
she did so in order to superimpose a crisis her government could not control on a pre-existing one it should have controlled better.

\begin{tabular}{|c|c|c|c|c|}
\hline & Severity & Causality & \begin{tabular}{|l|} 
Proposed \\
policy
\end{tabular} & $\begin{array}{l}\text { Support for } \\
\text { speaker }\end{array}$ \\
\hline Agrees & $\begin{array}{l}D P(1) ; N Z H \\
(2)\end{array}$ & $\begin{array}{l}D P(1) ; N Z H \\
(2)\end{array}$ & $N Z P(1) ; D P(1)$ & \\
\hline Disagrees & & & $D P(1)$ & \\
\hline $\begin{array}{l}\text { No comment/ } \\
\text { neutral }\end{array}$ & $\begin{array}{l}D P(1) ; N Z H \\
(1)\end{array}$ & $\begin{array}{l}D P(1) ; N Z H \\
(1)\end{array}$ & $N Z H(1)$ & $\begin{array}{l}D P(2) ; N Z H \\
(2)\end{array}$ \\
\hline
\end{tabular}

\section{Table 10.1 Media response to Clark's 23 May 2008 speech}

Note: $D P=$ Dominion Post NZH $=$ New Zealand Herald.

As the small numbers in Table 10.1 suggest, Clark's framing was to a degree buried by (perhaps more newsworthy) budget coverage focused on the content of Cullen's proposals. Where it was reported in detail, however, the papers largely accepted her emphasis on the severity of the global crisis (for instance, Janes 2008a). While Clark was successful in framing the importance of the global crisis, opinion polling suggests she was not able to escape blame for the home-grown downturn. Indeed, Labour suffered a shock drop in the polls (Morgan Research 2008b; One News-Colmar Brunton 2008b). Qualitative analysis can perhaps suggest the reason for this, with all of the articles analysed treating the budget as the key opportunity for Labour to reverse its poor approval ratings before the election. Clark's framing was widely perceived as a transparent attempt to pre-empt any generous tax cuts being offered by the National Party (New Zealand Herald 2008a). As such, while Clark's frame was accepted, she might have fallen victim to what the crisis literature describes as a 'credibility trap' through her overly partisan reading of the crisis (Boin et al. 2005:81).

\section{June 2008: Treasurer Cullen's reassurance attempt}

In the afternoon after the release of Statistics New Zealand's worrying quarterly GDP update, Finance Minister, Michael Cullen, delivered a brief speech reassuring New Zealanders that these data were attributable to a short-term shock. The framing within this brief speech was important, however, as it became a position Cullen would reiterate as a succession of concerning economic figures emerged in the next two months (Treasury 2008b). Cullen's speech was straightforward. He continued to attribute the crisis to external factors and to assert that the budgetary proposals were an appropriate policy response, as Clark and he had done earlier. Seeking to maintain confidence in the economy, however, he back-pedalled over its severity, which he now limited to the short term. Indeed, he described New Zealand's 'medium-term economic and social prospects' as 'very healthy and strong'. Cullen's downplaying of severity suggested that his 
sense making had advanced to the point that he was comprehending an international downturn creating a crisis of confidence in New Zealand, and that he decided to alter his frame in order to bolster confidence-a key part of the Finance Minister's economic leadership in any circumstance of uncertainty.

The most interesting aspect of Cullen's framing was its relationship to his sense making. He appeared to have backed away from the crisis rhetoric employed by himself and Clark in the budgetary debates, because he realised that the crisis was more serious than he had first appreciated. This could be attributable to Labour's punishment in the polls after the budget; however, it was just as likely to demonstrate an interesting unwillingness to curtail opportunistic crisis rhetoric if it could be detrimental to the economy.

\begin{tabular}{|l|l|l|l|l|}
\hline & Severity & Causality & $\begin{array}{l}\text { Proposed } \\
\text { policy }\end{array}$ & $\begin{array}{l}\text { Support for } \\
\text { speaker }\end{array}$ \\
\hline Agrees & $N Z H(1) ; P(1)$ & $N Z H(1) ; P(1)$ & $N Z H(1)$ & $N Z H(1)$ \\
\hline Disagrees & $D P(1) ; P(1)$ & $D P(1) ; P(1)$ & $D P(1)$ & \\
\hline $\begin{array}{l}\text { No comment/ } \\
\text { neutral }\end{array}$ & $N Z H(1) ; P(1)$ & $N Z H(1) ; P(1)$ & $P(3)$ & $\begin{array}{l}D P(1) ; N Z H \\
(1) ; P(3)\end{array}$ \\
\hline
\end{tabular}

\section{Table 10.2 Media response to Cullen's 27 June 2008 speech}

Note: $D P=$ Dominion Post NZH $=$ New Zealand Herald; $P=$ The Press.

The spread of numbers in Table 10.2 demonstrates how open the 'event-significance' framing contest over the global financial crisis was at the time of Cullen's speech. It is noteworthy that all of those disagreeing with his framing of the severity of the crisis argued that it was more severe. Those disagreeing with his causation were unwilling to excuse the government for the earlier domestic downturn. Moreover, the small number of articles simply represents the fact that at that point in New Zealand politics, the global financial crisis had not yet made it from the business pages into the mainstream news.

Qualitative analysis of the articles supported the claim that Cullen's speech occurred at a time of genuine uncertainty among commentators in New Zealand. Given this context, an attempt to maintain confidence was probably a responsible act by the Finance Minister. When opinion crystallised a week or so later, however, Cullen's optimistic medium-term forecast began to attract criticism, and would have attracted more had not the opposition's forecast been equally disproved (Eaton 2008; O'Sullivan 2008). This indicates that all framing contests are relative.

\section{October 2008: the Treasury's pre-election update}

On 6 October 2008, after two and a half months of worsening crisis and with the New Zealand economy now technically in recession, the Department of the 
Treasury released its Pre-Election Economic and Fiscal Update (PREFU), as required by the Public Finance Act 1989. Unparalleled among the cases studied in this volume, New Zealand's PREFU is a legally required, independent assessment of the nation's economic position before the beginning of the electoral period. As such, its sense making and framing of the crisis - while depoliticised and not an act of crisis exploitation - had a defining impact on subsequent acts of crisis exploitation by political leaders.

Within its projections, the $P R E F U$ defined the impact of the global financial crisis as 'severe', effectively closing off the event-significance framing contest to all subsequent frames. It projected that growth in the year to March 2009 was down to 0.1 per cent from 1.5 per cent in the May budget and would be rebounding in the next two years. Even more concerning for ordinary New Zealanders was its projection that unemployment was expected to rise to 5.1 per cent by March 2010 and could rise as high as 6.1 per cent in 2010. By necessary implication, the PREFU attributed the crisis to external factors, although it presented a range of policy options that left open the prospect of continued framing contests regarding management of the crisis.

The projections of the PREFU generally stood up to media criticism, although some reports cited independent research suggesting that the Treasury's projections could even have been slightly on the rosy side (Weir 2008a). The major effect of the PREFU's frame was to set the crisis as the defining issue of the electoral period and to immediately begin another framing contest between New Zealand's two dominant parties.

\section{October 2008: Cullen's response}

At the PREFU's release, and in direct response to its frame, Cullen gave a speech in which he abandoned his downplaying of the severity of the crisis and described the 'developments of recent weeks' as 'perhaps unprecedented in living memory'. This was, however, only partial abandonment, as he also stated that 'New Zealanders can feel a very high degree of confidence that New Zealand and Australia will emerge through these challenging times in better shape than many other developed nations'. He reinforced the Treasury's implicit attribution of causation to international developments, seemingly suggesting with the above statement that New Zealand's economic management before the crisis was superior to that of many other developed nations. Moreover, he strongly asserted that budgetary measures, such as 'the Government's strong infrastructure program' would be timely in their impact on this crisis. Simultaneously, he was expressly critical of any suggestion of further tax cuts in this context - a pointed attack on the advocacy of such cuts by opposition leader, John Key.

Situating Cullen's speech within the crisis-exploitation framework draws attention to the obvious connection between Cullen's speech and Labour's sense making 
after the PREFU. It is interesting to note, however, that this speech occurred before the decision to strongly exploit the crisis politically, which became evident five days later in Clark's 11 October speech act. The content of Cullen's frame was now type-2, following the emphatic demonstration of severity in the PREFU. In acknowledging severity, however, Cullen did not totally abandon the 'severity' framing contest, arguing that New Zealand's long-term prospects remained good, which would have significant implications in Clark's subsequent reframing. Cullen's clear intent was to mount a twofold pre-emptory defence: he aimed to demonstrate his budgetary measures were justified in the crisis while simultaneously using the crisis to pre-empt any National Party attempts to exceed his tax cuts.

Cullen's framing in this speech is perhaps most interesting for its restraint. This is especially true given the full-frontal assault against Key's economic philosophy launched in Clark's framing five days later. This suggests either that Labour had not decided yet to thoroughly exploit the crisis or, more likely, that they were waiting for Key to show his hand.

\begin{tabular}{|l|l|l|l|l|}
\hline & Severity & Causality & $\begin{array}{l}\text { Proposed } \\
\text { policy }\end{array}$ & $\begin{array}{l}\text { Support for } \\
\text { speaker }\end{array}$ \\
\hline Agrees & $D P(3) ; P(1)$ & $\begin{array}{l}D P(1) ; P(1) ; \\
N Z H(1)\end{array}$ & $D P(1)$ & $D P(1)$ \\
\hline Disagrees & $\begin{array}{l}D P(1) ; N Z H \\
(4)\end{array}$ & $\begin{array}{l}D P(2) ; N Z H \\
(3)\end{array}$ & $N Z H(2)$ \\
\hline $\begin{array}{l}\text { No comment/ } \\
\text { neutral }\end{array}$ & $N Z H(2)$ & $\begin{array}{l}D P(3) ; N Z H \\
(5)\end{array}$ & $\begin{array}{l}D P(1) ; P(1) ; \\
N Z H(2)\end{array}$ & $\begin{array}{l}D P(3) ; P(1) ; \\
N Z H(3)\end{array}$ \\
\hline
\end{tabular}

\section{Table 10.3 Media response to Cullen's 6 October 2008 speech}

Note: $D P=$ Dominion Post $; \mathrm{NZH}=$ New Zealand Herald $P=$ The Press.

Table 10.3 bears testimony to the polarising effect that such a momentous PREFU in an electoral context had within the commentariat. It is important to note, however, that all those who disagreed with Cullen's half-hearted framing of severity considered the crisis to be more severe, especially in terms of New Zealand's long-term economic prospects. Table 10.3 does evince a general dissatisfaction with Cullen's continued reliance on four-month-old budgetary solutions to a problem that now dwarfed the problems they were originally designed to address. This reliance on outdated framing was also significant in the qualitative analysis, which showed a general distaste among commentators for Cullen's attack on Key's further tax cuts - promised well before the crisis worsened (Cosgrove 2008; Oliver 2008). That said, much of the commentary on Cullen's frame, and certainly the opinion polling, was expectantly waiting for Key's post-PREFU response. 


\section{October 2008: the prime minister-in-waiting's big plan}

After the $P R E F U$, Key finally ventured a counter-frame to the Clark Government with his release of the 'National's economic management plan' on 8 October. While Key was not in government at this point, this speech has been included as one of his two speeches in this chapter's analysis because it was this initial framing of the crisis that carried him through the election and followed him into government. After the PREFU, Key acknowledged the severity of the crisis, although he chose to make only minor adjustments to his promised tax cuts - still outspending Labour. Unsurprisingly, Key sought to blame the incumbent government, suggesting that the 'suddenness and severity of the international downturn has exposed our economy's weaknesses more quickly than anyone would have expected', but asserting that those weakness had been 'present for some time'. He emphasised the need for the New Zealand economy to 'grow' out of the red ink and thus advanced policies directed towards long-term growth.

Key's speech is best characterised as a classic type-3, which attempted to utilise the economic crisis to expose deficiencies in Labour's economic management and economic policies. As such, Key's frame represents the first genuine challenge to Labour within the 'causality' framing contest. It is clear that Key's intent here was to frame the crisis in a manner favourable not just to a change in government, but to a major shift in macroeconomic management.

Within the crisis-exploitation framework, Key's framing demonstrated some of the advantages of opposition (see McCaffrie, this volume). As an opposition leader with a healthy (perhaps insurmountable) lead in the polls, Key was able to wait out the uncertainty of July and August 2008 until he had the data of the PREFU available to confirm his sense making (Morgan Research 2008c). His low-risk strategy also demonstrated the overarching narrative of the Clark Government's decline and the reality that the election was Key's to win or lose.

\begin{tabular}{|l|l|l|l|l|}
\hline & Severity & Causality & $\begin{array}{l}\text { Proposed } \\
\text { policy }\end{array}$ & $\begin{array}{l}\text { Support for } \\
\text { speaker }\end{array}$ \\
\hline Agrees & $D P(1)$ & $D P(1)$ & $\begin{array}{l}D P(1) ; N Z H \\
(3) ; P(2)\end{array}$ & $\begin{array}{l}D P(1) ; N Z H \\
(2) ; P(1)\end{array}$ \\
\hline Disagrees & $\begin{array}{l}D P(1) ; N Z H \\
(3)\end{array}$ & $\begin{array}{l}D P(1) ; N Z H \\
(5) ; P(2)\end{array}$ & $\begin{array}{l}D P(1) ; N Z H \\
(3) ; P(1)\end{array}$ \\
\hline $\begin{array}{l}\text { No comment/ } \\
\text { neutral }\end{array}$ & $\begin{array}{l}D P(2) ; P(7) ; \\
N Z H(8)\end{array}$ & $\begin{array}{l}D P(3) ; N Z H \\
(9) ; P(7)\end{array}$ & $\begin{array}{l}D P(2) ; N Z H \\
(3) ; P(3)\end{array}$ & $\begin{array}{l}D P(2) ; N Z H \\
(6) ; P(5)\end{array}$ \\
\hline
\end{tabular}

Table 10.4 Media response to Key's 8 October 2008 speech

Note: $D P=$ Dominion Post $; \mathrm{NZH}=$ New Zealand Herald $P=$ The Press. 
Table 10.4 demonstrates the difficulties of attempting to adopt a low-risk strategy in framing a crisis. Key's unwillingness to water down too much his electorally popular tax cuts accounts for much of the criticism apparent in Table 10.4, which was surprisingly high given Key's continued 10-point lead in the polls (Morgan Research 2008c; One News-Colmar Brunton 2008c). Indeed, qualitatively, almost all of the disagreements with Key could be attributed to his inability to adequately recognise the severity of the crisis and change his outdated tax policy (New Zealand Herald 2008b). Running through the criticism of Key was a sense of disappointment that, with his poll lead so substantial, his policy was not bolder. Indeed, one headline described him as a 'Prime minister in waiting... with an albatross for his rival' (New Zealand Herald 2008c), which captured well the extent to which the onus was on Labour to take political risks with the crisis.

\section{October 2008: Clark upping the ante}

At the Labour Party campaign launch, on 11 October, Clark decided to aggressively reframe the crisis in a final effort to stave off electoral defeat. From the stage of Auckland's Town Hall, Clark resurrected analogies to the Great Depression of the 1930s before declaring 'a curtain is being drawn on the era of the free wheeling unregulated money traders and financiers whose greed has shaken the international financial system to its very core'. In rhetoric reminiscent of US President Franklin D. Roosevelt's first inauguration speech, in which he made reference to the malicious 'moneylenders' as key culprits of the Great Depression, Clark attributed blame to 'greed merchants' who had destroyed 'the lives of ordinary people in real jobs trying to put food on the table for their families'. She then announced two new policies - a retail bank deposit guarantee and an additional stimulus package-before concluding by asking voters to consider who they 'really trust with the future of our economy'.

Situated within the crisis-exploitation framework, Clark's speech can be characterised as distinctly anti-status quo framing by an incumbent government. Clark's aggressive reframing should be characterised as the result of her acknowledgment that without dramatic action Labour would suffer electoral defeat. Her frame itself is an interesting mix of type- 2 and type- 3 , with the neo-liberal international status quo (and by implication its advocates within New Zealand) being identified as the critical threat to a still-prosperous domestic status quo produced under her government's stewardship. Clark's frame represented a decisive response to Key's contribution to the causality-framing contest three days earlier, with thinly veiled references to Key's background as a merchant banker in the description of 'greed merchants'. Finally, Clark's intention went further than just to exogenise blame from her government; she intended to apportion it to ideological stances similar to those advocated by the opposition. 


\begin{tabular}{|l|l|l|l|l|}
\hline & Severity & Causality & $\begin{array}{l}\text { Proposed } \\
\text { policy }\end{array}$ & $\begin{array}{l}\text { Support for } \\
\text { speaker }\end{array}$ \\
\hline Agrees & $\begin{array}{l}D P(2) ; N Z H \\
(4) ; P(1)\end{array}$ & $\begin{array}{l}D P(2) ; N Z H \\
(4) ; P(1)\end{array}$ & $\begin{array}{l}D P(2) ; N Z H \\
(4) ; P(1)\end{array}$ & $N Z H(1)$ \\
\hline Disagrees & & & & $N Z H(2) ; P(1)$ \\
\hline $\begin{array}{l}\text { No comment/ } \\
\text { neutral }\end{array}$ & $N Z H(2) ; P(1)$ & $N Z H(2) ; P(2)$ & $N Z H(2) ; P(1)$ & $\begin{array}{l}D P(1) ; N Z H \\
(3) ; P(1)\end{array}$ \\
\hline
\end{tabular}

\section{Table 10.5 Media response to Clark's 11 October 2008 speech}

Note: $D P=$ Dominion Post NZH $=$ New Zealand Herald $P=$ The Press.

Table 10.5 attests to a generally positive reception for Clark's framing. In particular, the solid support for the severity and causality of Clark's frame suggest she tapped into a longing within the electorate for more meaningful engagement with economic issues of great concern. The disparity in 'Support for speaker' reflects criticism from some commentators of Clark's transparent exploitation of the crisis for electoral gain - in particular, her announcement of a deposit guarantee without consulting the opposition. Interestingly, however, any loss of credibility was confined to the media, as after Clark's speech, Labour enjoyed a brief surge in the opinion polls, gaining on the National Party for the first time in the period (One News-Colmar Brunton 2008d). Clark's aggressive and initially successful crisis framing - which was reinforced consistently by her party during the election - was, however, not sufficient to sustain the trend. By the end of October, Key's lead - which never shrank substantially - was again widening, leading to his emphatic victory on 8 November (Ministry of Justice 2008).

\section{December 2008: the Treasury briefing to the incoming government}

After the election of the Key Government on 8 November 2008, another of the New Zealand Treasury's public information functions became relevant: the Briefing to an incoming minister. Again unparalleled among the other cases studied in this volume, in the briefing, the Treasury issues its independent, 'frank and fearless' public advice to the newly elected Minister of Finance. In December 2008 , this provided the public servants within the Treasury a second opportunity to provide an expert-driven, non-political view of the crisis.

In the briefing, Treasury defined the severity of the crisis as 'extremely challenging' and demanding of immediate action if the deterioration of the economy was to be stopped. Moreover, it argued against further short-term stimulus, claiming that the National Party's promised tax cuts went beyond what most other Organisation for Economic Cooperation and Development (OECD) nations were doing. It warned that living within the NZ\$1.75 billion spending cap the National Party had pledged to maintain would be difficult. Instead, 
Treasury suggested a shift in spending away from 'low-return' investments, such as lower staff-pupil ratios, to improving accountability for pupil achievement and the development of teaching practice; suggesting New Zealand superannuation might have to be less generous; and proposing alternative forms of tax restructuring.

Coming in the aftermath of the political game's climactic conclusion, Treasury's briefing represented a significant contribution to the framing of the crisis in the 'policy game' (see Chapter 2, this volume). As such, even though the new Finance Minister, Bill English, soundly rejected it (see below), the briefing provided an important alternative to the National Party's proposed structural reform of the economy.

\section{December 2008: the new Treasurer's reform bid}

On 5 December, English responded to the Treasury's briefing by advancing his own framing of the global financial crisis's impact on New Zealand. To give himself maximum room to manoeuvre, English opened his framing by acknowledging the severity of the crisis, stating that the government's books were likely to get worse before they got better. He then moved quickly to attribution of responsibility, which he placed squarely on 'Labour's complacency and refusal to address structural issues dragging down our growth potential', which increased the vulnerability of the New Zealand economy to global developments. English then advocated a policy response based on the removal of 'barriers that have prevented New Zealand becoming more competitive and achieving higher productivity growth'.

It was clear that English's framing followed recognition of the crisis as a critical opportunity for his party to advance its structural economic reforms early in its term. He sought to endogenise as much blame as possible, targeting the policies of the previous government. His intention appeared to be to build public sentiment behind neo-liberal economic reforms by discrediting the status quo. This framing of the global financial crisis to build support for centre-right, neo-liberal reforms was remarkable given that the same crisis had, in almost all other instances, been framed to the opposite effect. For example, in New Zealand's close neighbour and financial trading partner Australia, Prime Minister, Kevin Rudd, used the crisis to proclaim the death of 'neo-liberalism' (Rudd 2009; see further Laing and Tindall, this volume). 


\begin{tabular}{|c|c|c|c|c|}
\hline & Severity & Causality & $\begin{array}{l}\text { Proposed } \\
\text { policy }\end{array}$ & $\begin{array}{l}\text { Support for } \\
\text { speaker }\end{array}$ \\
\hline Agrees & & & $N Z H(1)$ & $N Z H(1)$ \\
\hline Disagrees & & & $P(1)$ & \\
\hline $\begin{array}{l}\text { No comment/ } \\
\text { neutral }\end{array}$ & $\begin{array}{l}D P(1) ; N Z H \\
(2) ; P(1)\end{array}$ & $\begin{array}{l}D P(1) ; N Z H \\
(2) ; P(1)\end{array}$ & $\begin{array}{l}D P(1) ; N Z H \\
(1)\end{array}$ & $\begin{array}{l}D P(1) ; N Z H \\
(1) ; P(1)\end{array}$ \\
\hline
\end{tabular}

Table 10.6 Media response to English's 5 December 2008 speech

Note: $D P=$ Dominion Post NZH $=$ New Zealand Herald $P=$ The Press.

Table 10.6 shows the somewhat muted media response to English's framing. Much of this reaction can be attributed to the honeymoon period English was enjoying, with the neutral responses effectively meaning acquiescence to the National-led Government's mandated agenda. Qualitatively, it is remarkable the commentary did not address the extent to which English was going against the grain of international developments. This was especially significant given that the Treasury's briefing pointed out expressly that the National Party's program of tax cuts was out of step with the rest of the OECD (Treasury 2008b).

\section{December 2008: the bank governor's warning}

Having been compelled by convention to keep a low profile during the election, RBNZ Governor, Dr Alan Bollard, on 10 December 2008, felt at liberty to advance his framing of the crisis. He re-emphasised the severity of the crisis, warning that the road to recovery for New Zealand would be long. In particular, he expressed concerns about high inflation, which had to be reduced before the RBNZ could ease monetary policy to stimulate the economy. Moreover, he warned that falling international commodity prices could not be relied on to automatically reduce short inflation, as the operation of other factors such as the exchange rate, taxes and firms' margins could result in a lag of six months or more. Bollard, not just attributing the continuance of the crisis to external factors, warned that all sectors of the economy would need to refrain from adding inflationary pressures if New Zealand was to recover in the short term.

While it was not really picked up by the media, Bollard's post-election framing of the crisis was particularly significant for two reasons. First, after the electoral populism of the politicians, Bollard's speech represented the first attempt to advance a framing of the context specific to business leaders who-beyond the short-term calculus of an electoral contest-were a key audience for the government's economic management and for the outcome of the 'policy game'. The second reason for the importance of Bollard's framing was its focus on immediate challenges, which highlighted weaknesses in the more long-term, policy-oriented framing attempts by English and the Treasury. The immediacy of these short-term challenges was to become even more apparent eight days 
later with the Treasury's release of its Economic and Fiscal Forecasts (Treasury 2008e).

\section{December 2008: further bad news from English}

After the sharp deterioration of New Zealand's economic forecast in the Treasury's Economic and Fiscal Forecasts, Finance Minister English was compelled to reframe the severity of the crisis - in particular, for the next 12 months. English described the new Treasury forecast of 'sharply increasing public sector debt and higher fiscal deficits over the next five years' to be 'outside the range the government considered prudent'. This led English to hint at a policy response that appeared to be in tension with his government's promised tax cuts-notably: 'putting the economy on a strong medium to long-term footing, limiting spending growth, getting better value out of existing spending, ensuring that tax bases are maintained, and ensuring that government assets were managed as effectively as possible'.

It was clear that Treasury's December forecasts overtook English's initial sense making, particularly with regard to the short to medium-term urgency of the crisis. With this frame, English shifted his position and was now attributing far more blame to international developments (the Clark Government was not even mentioned). His intention was most likely to frame the crisis in a way that acknowledged the enormity of the challenge facing his government but also bolstered public confidence in their ability to achieve it.

\begin{tabular}{|l|l|l|l|l|}
\hline & Severity & Causality & $\begin{array}{l}\text { Proposed } \\
\text { policy }\end{array}$ & $\begin{array}{l}\text { Support for } \\
\text { speaker }\end{array}$ \\
\hline Agrees & $N Z H(2)$ & & $N Z H(2)$ & \\
\hline Disagrees & $D P(2)$ & & $D P(1)$ & \\
\hline $\begin{array}{l}\text { No comment } \\
\text { neutral }\end{array}$ & $\begin{array}{l}D P(1) ; N Z H \\
(1) ; P(1)\end{array}$ & $\begin{array}{l}D P(3) ; N Z H \\
(3) ; P(1)\end{array}$ & $\begin{array}{l}D P(2) ; N Z H \\
(1) ; P(1)\end{array}$ & $\begin{array}{l}D P(3) ; N Z H \\
(3) ; P(1)\end{array}$ \\
\hline
\end{tabular}

\section{Table 10.7 Media response to English's 18 December 2008 speech}

Note: $D P=$ Dominion Post $; \mathrm{NZH}=$ New Zealand Herald; $P=$ The Press.

The quantitative analysis in Table 10.7 reveals that when it came to the economic crisis, English's honeymoon in the press was cut short. Qualitative analysis emphasises this point. For the first time during the period, a genuinely alarmist didactic ran through much of the commentary as it began to come to terms with the prospect of sizeable budget deficits into the foreseeable future (for example, Weir 2008b). Some commentators looking further ahead warned of long-term difficulties such as accelerated infrastructure drift to Australia and even an unfavourable structural realignment of the international economy (for example, Janes 2008b). 


\section{February 2009: the bank governor at the 'Jobs Summit'}

The final two speech acts to be analysed both occurred at the Key Government's 'Jobs Summit' on 27 February 2009. This summit was intended to generate ideas for the Key Government in preparing its first critically important crisis budget. Even though it occurred slightly after Key's opening address, Bollard's speech will be analysed first, as it provided the authoritative frame of the crisis for the summit.

In framing the impact of the global financial crisis at the Jobs Summit, Bollard re-engaged in the first framing context to curtail the sweeping use of historical analogy in describing the severity of the crisis. Bollard emphasised: 'to be clear, the state of the global economy and the outlook are very serious, but we are nowhere near Depression-level economic condition.' Using a more apt historical analogy, Bollard described the present crisis in world growth terms as 'somewhat below the early 1980s recession'. Bollard then framed the effect of the crisis as one of producing a 'new global balance', which in broad terms meant that economies such as New Zealand's would 'have to save more, reduce household deficits, build exports and improve their external balances'. Bollard concluded that within the Western world, 'New Zealand's economy and financial system are relatively well-placed to weather the adjustment. Our challenge will be to remain well-positioned to take advantage of the economic recovery when it comes'.

This framing by Bollard is significant in its context at the opening of the Jobs Summit. As the summit itself was an attempt to restore confidence in the economy through coopting New Zealand's business elite, it was critical to open with a relatively positive framing of the crisis. As the country's key financial technocrat, Governor Bollard was in a uniquely credible position to provide this. His authority was evident from universal acceptance of his frame.

\section{February 2009: the new Prime Minister's call to action}

The final speech act to be analysed in this chapter was delivered by Prime Minister Key in opening the Job Summit. The summit, a brainchild of his government, was intended as a forum to produce ideas before the delivery of his government's first budget in May, which inevitably was to be cast as a crisis-response budget. If nothing else, it represented a tremendous opportunity for the Key Government to close a credibility grab in bringing New Zealand's most respected economic minds into line behind its frame.

Key opened his address by framing the problem as one about which something could be done. He scolded that 'we will not gain anything today or in the months ahead if we become lost in hand-wringing and crystal ball gazing about how bad things are'. As such, he framed himself and the participants at the summit into the crisis as 'doers'. 
The Job Summit followed from the sense making of the Key Government that the economic crisis was going to be a defining feature of its term, and from a decision to gain external credibility in order to assist its framing of the crisis. Key's framing represented a step back from the type- 2 frame adopted late in December by English, in so much that blame for the crisis was not totally exogenised to international factors. It was important for Key to show that the government and the country's chief economic players would be able to 'do' something about it. Key appeared to be focused on gaining external credibility for his government's frame, while ignoring internal sources of credibility, such as the consistency of the frame itself.

\begin{tabular}{|l|l|l|l|l|}
\hline & Severity & Causality & $\begin{array}{l}\text { Proposed } \\
\text { policy }\end{array}$ & $\begin{array}{l}\text { Support for } \\
\text { speaker }\end{array}$ \\
\hline Agrees & & & $N Z H(1)$ & $N Z H(1)$ \\
\hline Disagrees & $\begin{array}{l}D P(1) ; N Z H \\
(2) ; P(1)\end{array}$ & $\begin{array}{l}D P(1) ; N Z H \\
(2)\end{array}$ & $N Z H(2)$ \\
\hline $\begin{array}{l}\text { No comment/ } \\
\text { neutral }\end{array}$ & $\begin{array}{l}D P(1) ; N Z H \\
(3)\end{array}$ & $\begin{array}{l}D P(2) ; N Z H \\
(5) ; P(1)\end{array}$ & $\begin{array}{l}D P(1) ; N Z H \\
(2) ; P(1)\end{array}$ & $\begin{array}{l}D P(1) ; N Z H \\
(2) ; P(1)\end{array}$ \\
\hline
\end{tabular}

Table 10.8 Media response to Key's 27 February 2009 speech

Note: $D P=$ Dominion Post NZH $=$ New Zealand Herald $P=$ The Press.

Table 10.8 suggests that the media response to the Job Summit address, and indeed to the summit itself, was mixed. It is true that some of the 'No comment/ neutral' articles that merely reported the advent of such an august gathering would have served Key's purpose of increasing his government's credibility. The solid portion of articles that disagreed with the severity of Key's frame as well as his policy response can, however, be attributed to the sentiment that a summit was not an appropriate response to a crisis of this scale (for example, Van Beynen 2009). The pervasiveness of this critique of 'trivialisation' throughout the media coverage served to partially undermine the momentum Key might have hoped to obtain for his proposed reforms.

\section{Framing the financial crisis in New Zealand: analysis and conclusions}

Having analysed the attempts to frame the global financial crisis by key New Zealand leaders, it is possible to draw some conclusions about the impact of crisis exploitation within the case. In particular, it is useful to focus on the two 'games' that lie at the core of crisis exploitation: the political game and the policy game (see Chapter 2, this volume).

In terms of the political game in New Zealand, the impact of crisis exploitation was noted, but probably not decisive. The National Party, led by John Key, maintained its convincing lead in the polls throughout and was eventually 
electorally successful. In one sense, this could be seen as a justification for those who argue that already-popular leaders are more likely to emerge successfully from a crisis situation (Wilkins 1987; Seeger et al. 2003). Such an inference would, however, ignore two important conclusions from the case. First, the Clark Government's crisis exploitation - while unsuccessful - did have a noticeable impact on the polls. Its ultimate failure is explained just as well by the Key opposition's competent crisis leadership as it is by Key's general popularity. Moreover, throughout the period, the actions of all key players could be accommodated within a crisis-exploitation framework. This suggests, if nothing else, that the actors themselves considered crisis management to be of significant importance and they acted accordingly. In the terms outlined in the 'political game', an unpopular incumbent attempts first to minimise blame (box I) but then chooses to risk a blame showdown (box IV) in a last-ditch effort to reverse an imminent electoral defeat. This behaviour might be different to that posited as likely, ceteris paribus, in Chapter 2, but it can nonetheless be accommodated within the framework. Indeed, this chapter found such an accommodation to be illuminating.

It is in the context of the 'policy game' (see Chapter 2, this volume), however, that the utility of the framework is borne out. An interesting anomaly of the case, noted above in the analysis of English's first speech act analysed in this chapter, is the extent to which the Key Government was successful at exploiting the economic crisis to implement 'neo-liberal' economic reforms. Such reforms were anomalous because in almost all other countries, including New Zealand's close neighbour and financial partner Australia, the global financial crisis had led to the discrediting of neo-liberal economics.

Such a disparity in policy response between two close neighbours suggests the policy outcomes of crises are shaped by much more than the content of the crisis itself; it suggests the crisis framing is of the utmost importance to the policy outcomes. Boin et al.'s (2009) conception of a 'policy game' would seem an efficacious way to theoretically model this policy side of the framing contest. In the case of New Zealand, box III of Table 2.2 (Chapter 2) would seem to explain the neo-liberal outcome; there had been a major and swift rhetorical/symbolic change in New Zealand economic policy after the crisis, which was successfully framed as a consequence of New Zealand's lack of competitiveness in global markets.

The key question remains: what determined success in these framing contests? Considering the political and policy games in New Zealand together, it seems there was one factor that could incorporate the impact of popularity and that of a persuasive crisis in explaining causation: credibility. Elsewhere, credibility has been considered to constitute the key factor in determining the success of 'meaning making' after a crisis (Boin et al. 2005:79-83). In the New Zealand case 
study, its significance seems to be demonstrated. The insurmountable challenge for the Clark Government was not unpopularity so much as the 'credibility trap': any attempt to exploit the crisis to reverse this unpopularity without that intention becoming transparent. Moreover, the Key Government's early success in implementing significant neo-liberal policy reform would seem best explained by its ability to frame a crisis that struck during a home-grown downturn as being linked to the economic management that caused that downturn. If there is one salient lesson that the unique case of New Zealand should suggest to the scholar of crisis leadership, it is therefore the importance of credibility as a determinant in the political and policy outcomes of crises.

\section{References}

Bennet, A. 2008, 'Depositor's fears sparked savings pledge-Bollard', New Zealand Herald, 14 October.

Boin, A., 't Hart, P., Stern, E. and Sundelius, B. 2005, The Politics of Crisis Management: Public leadership under pressure, Cambridge University Press, Cambridge.

Boin, A., 't Hart, P. and McConnell, A. 2009, 'Crisis exploitation: political and policy impacts of framing contests', Journal of European Public Policy, vol. 16, no. 1, pp. 81-106.

Bollard, A. 2007, Financial stability report, Press release, 7 November, Reserve Bank of New Zealand, viewed 21 May 2009, <http://www.rbnz.govt.nz/finstab/fsreport/3162330.pdf>

Bollard, A. 2008a, March monetary policy statement, Press release, 6 March, Reserve Bank of New Zealand, viewed 21 May 2009, <http://www.rbnz.govt.nz/news/2009/3581433.html>

Bollard, A. 2008b, The New Zealand economic outlook, Press release, 28 March, Reserve Bank of New Zealand, viewed 21 May 2009, <http://www.rbnz.govt.nz/news/2008/3275909.html>

Bollard, A. 2008c, Financial stability report, Press release, 7 May, Reserve Bank of New Zealand, viewed 21 May 2009, <http://www.rbnz.govt.nz/news/2008/3310327.html>

Bollard, A. 2008d, June monetary policy statement, Press release, 5 June, Reserve Bank of New Zealand, viewed 21 May 2009, <http://www.rbnz.govt.nz/news/2007/3032038.html>

Bollard, A. 2008e, September monetary policy statement, Press release, 11 September, Reserve Bank of New Zealand, viewed 21 May 2009, <http://www.rbnz.govt.nz/news/2008/3416797.html> 
Bollard, A. 2008f, Financial stability report, Press release, 12 November, Reserve Bank of New Zealand, viewed 21 May 2009, <http://www.rbnz.govt.nz/news/2008/3484984.html>

Bollard, A. 2008g, December monetary policy statement, Press release, 4 December, Reserve Bank of New Zealand, viewed 21 May 2009, $<$ http://www.rbnz.govt.nz/news/2008/3504509.html>

Bollard, A. 2008h, Speech to the Wellington Chamber of Commerce, 18 December, Reserve Bank of New Zealand, viewed 9 May 2009, <http://www.rbnz.govt.nz/speeches/3509648.html>

Bollard, A. 2009, 'Speech to Jobs Summit', New Zealand Herald, 27 February, viewed 22 May 2009, $<$ http://www.nzherald.co.nz/nz/news/article.cfm?c_id=1\&objectid=10559061>

Clark, H. 2008a, Budget speech to Auckland Chamber of Commerce, 23 May, viewed 10 May 2009, <http://www.beehive.govt.nz/speech/ budget+speech+auckland+chamber+commerce $>$

Clark, H. 2008b, Labour Party campaign launch speech, 13 October, viewed 10 May 2009, <http://www.scoop.co.nz/sotires/PA0810/S00261.htm>

Cosgrove, R. 2008, 'Labour horrific', The Press, 9 October.

Cullen, M. 2008a, Budget 2008: a fair economy, a strong future, Speech, 22 May, viewed 10 May 2009, <http://www.beehive.govt.nz/budget2008>

Cullen, M. 2008b, March GDP weak as expected, NZ future is strong, Press release, 27 June, viewed 7 May 2009, <http:/www.beehive.govt.nz/ release $/$ march + gdp + weak + expected $+\mathrm{nz}+$ future + strong $>$

Cullen, M. 2008c, Pre-election economic and fiscal update 2008, Speech, 6 October, viewed 10 May 2008, <http://www.beehive.govt.nz/ speech/pre-election+economic +and+fiscal+update $+2008>$

Eaton, D. 2008, 'Country now in recession', The Press, 6 August.

English, W. 2008a, Crown accounts show need for urgent economic action, Press release, 5 December, viewed 30 May 2009, $<$ http://www.beehive.govt.nz/release/ crown + accounts + show + need + economic + action $>$

English, W. 2008b, Government committed to plan for steering NZ through global turmoil, Press release, 18 December, viewed 30 May 2009, $<$ http://www.beehive.govt.nz/release/ government+committed + plan + steering + nz+through + global+turmoil $>$

Janes, A. 2008a, 'She's chalk and he's all cheese', Dominion Post, 24 May, p. 2. Janes, A. 2008b, 'Capital punishment', Dominion Post, 20 December. 
Key, J. 2008, National's economic management plan, 8 October, viewed 10 May 2009, <http://www.national.org.nz/ Article.aspx?ArticleID=28682>

Key, J. 2009, Opening address to the Jobs Summit, 27 February, viewed 30 May 2009, <http://www.nzherald.co.nz/ politics/news/article.cfm?c_id $=280 \&$ objectid $=10559036>$

Ministry of Justice 2008, Election Results 2008, 9 November, Ministry of Justice, viewed 30 May 2009, <http://2008.electionresults.govt.nz/partystatus.html>

Morgan Research 2008a, New Zealand preferred party poll: 7-20 April, 24 April, Morgan Research, viewed 30 May 2009, <http://www.roymorgan.com/news/polls/2008/4288/>

Morgan Research 2008b, New Zealand preferred party poll: May, 5 June, Morgan Research, viewed 30 May 2009, <http://www.roymorgan.com/news/polls/2008/4298/>

Morgan Research 2008c, New Zealand preferred party poll: July 14-27, 1 August, Morgan Research, viewed 30 May 2009, <http://www.roymorgan.com/news/polls/2008/4311/>

Morgan Research 2008d, New Zealand consumer confidence drops 5.5pts to 100.1, 19 December, Morgan Research, viewed 30 May 2009, <http://www.roymorgan.com/news/polls/2008/828/>

New Zealand Herald 2008a, 'Cullen's ninth seeks to snooker the National Party over bigger tax cuts', New Zealand Herald, 23 May.

New Zealand Herald 2008b, 'Time now for Fiscal boldness', New Zealand Herald, 8 October.

New Zealand Herald 2008c, 'Prime Minister in waiting... with an albatross for his rival', New Zealand Herald, 8 October.

New Zealand Herald 2009, 'Challenges heavier than job solutions', New Zealand Herald, 28 February.

New Zealand Institute of Economic Research (NZIER) 2008, Quarterly Survey of Business Opinion, 8 July, New Zealand Institute of Economic Research, viewed 22 June 2009,

$<$ http://nzier.org.nz/includes/download.aspx?ID=95667>

Nielson Media Research New Zealand 2008, National readership survey results: newspaper readership, January-December, Nielson Media Research New Zealand, viewed 10 May 2009, $<$ http://www.nielsenmedia.co.nz/MRI_pages.asp?MRID=35>

O'Sullivan, F. 2008, 'Muck but where's the pony?', New Zealand Herald, 6 August. 
Oliver, P. 2008, 'Cullen rains on Key's parade', New Zealand Herald, 7 October. One News-Colmar Brunton 2008a, 'Preferred Party Poll', April, One News-Colmar Brunton, viewed 30 May 2009, <http://tvnz.co.nz/view/page/425825/1728614>

One News-Colmar Brunton 2008b, 'Preferred Party Poll', May, One News-Colmar Brunton, viewed 30 May 2009, $<$ http://images.tvnz.co.nz/tvnz_images/news2008/colmar_brunton/ may08/May08_partysupport.pdf >

One News-Colmar Brunton 2008c, 'Preferred Party Poll', 5 October, One News-Colmar Brunton, viewed 30 May 2009, <http://tvnz.co.nz/view/page/1318360/2176207>

One News-Colmar Brunton 2008d, 'Preferred Party Poll', 19 October, One News-Colmar Brunton, viewed 30 May 2009, <http://tvnz.co.nz/view/page/576182/2216673>

Rudd, K. 2009, 'Essay: the global financial crisis', The Monthly, February, pp. 26-38.

Seeger, M. W., Sellnow T. L. and Ulmer, R. R. 2003, Communication and Organisational Crisis, Praeger, Westport, Conn.

Statistics New Zealand 2008, Gross domestic product: March quarter, Media release, 27 June, Statistics New Zealand, viewed 30 May 2009, $<$ http://www.stats.gov.nz/store/2008/06/ gross-domestic-product-mar08qtr-mr.htm $>$

Treasury 2008a, Budget Economic and Fiscal Update, 22 May, Department of the Treasury, viewed 14 May 2009, <http://www.treasury.govt.nz/budget/forecasts/befu2008>

Treasury 2008b, Overview of July Economic Indicators, 5 August, Department of the Treasury, viewed 14 May 2009, $<$ http://www.treasury.govt.nz/economy/mei/archive/pdfs/mei-jul08.pdf>

Treasury 2008c, Pre-Election Economic and Fiscal Update, 6 October, Department of the Treasury, viewed 14 May 2009, <http://www.treasury.govt.nz/budget/forecasts/prefu2008>

Treasury 2008d, Briefing to the Incoming Minister of Finance 2008: Medium-term economic challenges, Briefing Paper, 4 December, Department of the Treasury, viewed 14 May 2009, <http://www.treasury.govt.nz/publications/briefings/2008/big08.pdf>

Treasury 2008e, Economic and Fiscal Forecasts, 18 December, Department of the Treasury, viewed 14 May 2009, <http://www.treasury.govt.nz/budget/forecasts/eff2008/effo8.pdf> 
TV3-TNS 2008, 'Preferred Party Poll', 10-16 April, TV3-TNS, viewed 30 May 2009, <http://img.scoop.co.nz/media/pdfs/0804/3poll200408.pdf>

Van Beynen, M. 2009, 'Gabfest needs to be do-fest', The Press, 28 February.

Weir, J. 2008a, 'That "rainy day" has arrived', Dominion Post, 7 October.

Weir, J. 2008b, 'Watch your speedos when rain turns to a hurricane', Dominion Post, 7 October.

Wilkins, L. 1987, Shared Vulnerability: The media and American perceptions of the Bhopal disaster, Greenwood Press, New York. 